\title{
Fermentation of Trihydroxybenzenes by Pelobacter acidigallici gen. nov. sp. nov., a New Strictly Anaerobic, Non-Sporeforming Bacterium
}

\author{
Bernhard Schink and Norbert Pfennig \\ Fakultät für Biologie, Universität Konstanz, Postfach 5560, D-7750 Konstanz, Federal Republic of Germany
}

\begin{abstract}
Five strains of rod-shaped, Gram-negative, nonsporing, strictly anaerobic bacteria were isolated from limnic and marine mud samples with gallic acid or phloroglucinol as sole substrate. All strains grew in defined mineral media without any growth factors; marine isolates required salt concentrations higher than $1 \%$ for growth, two freshwater strains only thrived in freshwater medium. Gallic acid, pyrogallol, 2,4,6-trihydroxybenzoic acid, and phloroglucinol were the only substrates utilized and were fermented stoichiometrically to $3 \mathrm{~mol}$ acetate (and $1 \mathrm{~mol} \mathrm{CO}_{2}$ ) per mol with a growth yield of $10 \mathrm{~g}$ cell dry weight per mol of substrate. Neither sulfate, sulfur, nor nitrate were reduced. The DNA base ratio was $51.8 \%$ guanine plus cytosine. A marine isolate, Ma Gal 2, is described as type strain of a new genus and species, Pelobacter acidigallici gen. nov. sp. nov., in the family Bacteroidaceae. In coculture with Acetobacterium woodii, the new isolates converted also syringic acid completely to acetate. Cocultures with Methanosarcina barkeri converted the respective substrates completely to methane and carbon dioxide.
\end{abstract}

Key words: Pelobacter acidigallici gen. nov. sp. nov. - Genus and species description - Phenolic compounds - Gallic acid - Pyrogallol - Phloroglucin - Anaerobic degradation Acetate - Methanogenic cultures

The complete anaerobic degradation of lignin derivatives including ferulic acid, vanillic acid and other methoxylated phenolic compounds by mixed bacterial populations was reported already by Tarvin and Buswell (1934) and was again proven recently in more refined studies (Healy and Young 1978, 1979; Healy et al. 1980). The organisms involved in these processes have not yet been identified. From anaerobic enrichments on methoxylated phenol derivatives recently Acetobacterium woodit was isolated. This organism fermented the methoxyl groups to acetate and did not attack the aromatic ring (Bache and Pfennig 1981). In the present study pure cultures of new organisms are described which degrade two trihydroxybenzene isomers fermentatively and produce exclusively acetate and $\mathrm{CO}_{2}$ as products.

\section{Materials and Methods}

Source of Organisms

The following strains were isolated in pure culture from enrichment cultures inoculated with mud samples:

1. Strains Ma Gal 1, Ma Gal 2 and Ma Phl 1 from black, anaerobic mud of Rio Marin, a channel about $2.5 \mathrm{~m}$ wide and $70 \mathrm{~cm}$ deep located in the city of Venice, Italy. Similar isolates were also obtained from a black mud sample of the Canale Grande in Venice, Italy, and from marine black mud taken near Cuxhaven, W. Germany.

2. Strains Ott Gal 1 and Ott Gal 2 from black, anaerobic mud of a pasture creek near Hannover, W. Germany. Similar isolates were also obtained from another freshwateer creek mud near Konstanz, W. Germany, and also from anaerobic digestor sludge of sewage plants.

Methanospirillum hungatei strain $\mathrm{M} 1 \mathrm{~h}$ was isolated from digested sludge of the sewage plant of Göttingen, W. Ger-<smiles>O=C(O)c1cc(O)c(O)c(O)c1</smiles>

Gallic acid<smiles>Oc1cccc(O)c1O</smiles>

Pyrogallol<smiles>O=C(O)c1c(O)cc(O)cc1O</smiles>

2.4.6-Trihydroxybenzoic acid<smiles>Oc1cc(O)cc(O)c1</smiles>

Phloroglucinol<smiles>COc1cc(C(=O)O)cc(OC)c1O</smiles>

Syringic acid<smiles>Oc1ccc(O)c(O)c1</smiles>

Hydroxy-

hydroquinone<smiles>O=C(O)C=Cc1cc(O)c(O)c(O)c1</smiles>

3.4.5-Trihydroxycinnamic acid 
many. Methanosarcina barkeri strain Fusaro (DSM 804) was obtained from the Deutsche Sammlung für Mikroorganismen, Göttingen. Desulfovibrio vulgaris strain Marburg was kindly provided by Prof. Dr. R. K. Thauer, Marburg.

\section{Media and Growth Conditions}

The basal medium had the following composition (values in g/1): $\mathrm{KH}_{2} \mathrm{PO}_{4}, 0.2 ; \mathrm{NH}_{4} \mathrm{Cl}, 0.25 ; \mathrm{KCl}, 0.5 ; \mathrm{CaCl}_{2} \cdot 2 \mathrm{H}_{2} \mathrm{O}$, 0.15 . Freshwater medium in addition contained $1.0 \mathrm{~g} \mathrm{NaCl}$ and $0.4 \mathrm{~g} \mathrm{MgCl}_{2} \cdot 2 \mathrm{H}_{2} \mathrm{O}$, marine medium $20.0 \mathrm{~g} \mathrm{NaCl}$ and $3.0 \mathrm{~g} \mathrm{MgCl} 2 \cdot 2 \mathrm{H}_{2} \mathrm{O}$ per liter. Sodium bicarbonate, sodium sulfide, trace element solution SL 7 and vitamin solution (Pfennig 1978) were added to the autoclaved, cooled medium from stock solutions as described in detail (Widdel and Pfennig 1981). The $\mathrm{pH}$ was adjusted to $7.2-7.3$. For enrichment cultures, the medium was dispensed à $50 \mathrm{ml}$ into $100 \mathrm{ml}$ serum bottles gassed with $\mathrm{N}_{2} / \mathrm{CO}_{2}$ mixture $(80 \% / 20 \%)$ and sealed with butyl rubber stoppers or, for pure cultures, into rubber-sealed $50 \mathrm{ml} \mathrm{screw} \mathrm{cap} \mathrm{bottles} \mathrm{or} 20 \mathrm{ml}$ screw cap tubes which were completely filled. Substrates were added $5 \mathrm{mM}$ from sterile stock solutions before inoculation. Phenolic substrates were filter-sterilized as $0.1 \mathrm{M}$ or $0.2 \mathrm{M}$ ( $\mathrm{NaOH}$-neutralized) solutions and stored under nitrogen gas. Growth of pure cultures was followed in $20 \mathrm{ml}$ tubes in a Bausch and Lomb-Spectronic 70 spectrophotometer. In tests for syntrophic growth excess of pure cultures of Methanospirillum hungatei, Methanosarcina barkeri or Desulfovibrio vulgaris was added, the latter with additional sodium sulfate ( $20 \mathrm{mM}$ final concentration added from sterile $1 \mathrm{M}$ stock solution). For further characterization, also commercial media systems (API $20 \mathrm{~A}$, BioMerieux, Nürtingen, W. Germany) were applied. Aerobic growth was tested in agar shake gradient cultures under air. All growth tests were carried out at least in duplicates at $28^{\circ} \mathrm{C}$.

\section{Isolation}

Pure cultures were obtained by repeated application of the agar shake culture method as described by Pfennig (1978). Tubes were gassed with $\mathrm{N}_{2} / \mathrm{CO}_{2}$ mixture (80/20) and sealed with butyl rubber stoppers. Purity was checked microscopically and also by growth test in complex medium (ACmedium, Difco-Laboratories, Detroit, Michigan, USA).

Gram-staining was carried out according to Magee et al. (1975) as modified by Widdel (1980) without counterstaining. Acetobacterium woodii and Escherichia coli were used as control strains.

\section{Chemical Analyses}

Sulfide formation from sulfur or sulfate was analyzed by the methylene blue method (Pachmayr 1960). Formation of nitrite from nitrate was assayed by azo dye formation with sulfanilic acid and $\alpha$-naphthylamine. Phenolic substrates were quantified by absorption spectra taken at $200-350 \mathrm{~nm}$. wavelength in a Gilford model 250 spectrophotometer.

Lactate was assayed photometrically with $\mathrm{D}$ - and $\mathrm{L}$-lactate dehydrogenase according to Bergmeyer (1965).

Acetate, other volatile fatty acids, and alcohols were assayed by gas chromatography on Porapak QS, $100-$ 120 mesh, Column length $2.0 \mathrm{~m}, 1 / 4^{\prime \prime}$ diameter, in a PerkinElmer Sigma $3 \mathrm{~B}$ gas chromatograph with flame ionization detector, injector and detector temperature $250^{\circ} \mathrm{C}$, oven temperature $220^{\circ} \mathrm{C}$, carrier gas nitrogen, $30 \mathrm{ml} / \mathrm{min}$. Samples were acidified prior to injection with formic acid from $10 \mathrm{M}$ stock solution to $0.5 \mathrm{M}$ final concentration.

Methane was quantified in a Perkin-Elmer Sigma $4 \mathrm{~B}$ gas chromatograph equipped with a molecular sieve column ( $5 \AA$, $\left.60 / 80 \mathrm{mesh}, 1.8 \mathrm{~m}, 1 / 8^{\prime \prime}\right)$ and a flame ionization detector.

\section{DNA Base Composition}

The mole per cent guanine plus cytosine of the DNA was determined with the thermal denaturation method according to De Ley (1970) after extraction as described by Marmur (1961).

\section{Results}

\section{Enrichment, Isolation, and Enumeration}

$50 \mathrm{ml}$ - enrichments in freshwater medium with $5 \mathrm{mM}$ gallic acid or $5 \mathrm{mM}$ phloroglucinol were inoculated with $3-5 \mathrm{ml}$ of anaerobic freshwater mud from various creeks or of sludge from sewage plants. Marine medium was used in the same manner for enrichments from marine mud samples from Venice and Cuxhaven. Gas production started after 512 days and ceased after $3-4$ weeks. In subcultures on the same media turbidity developed within $2-3$ days but gas production was small and the $\mathrm{pH}$ dropped from 7.2 to 6.3-6.5. Further subcultures were run alternatively with and without high background populations of Methanospirillum hungatei in order to promote a possible electron transfer towards methanogenesis. Independently of added methanogens the same type of rod-shaped bacteria developed in all subcultures. By fluorescence microscopy no methanogenic bacteria other than those added could be detected. Isolation was attempted in agar shake series with and without Desulfovibrio vulgaris added as a hydrogen sink. In both cases the same yellowish, lens-shaped colonies developed which were picked with sterile Pasteur pipettes, resuspended in small amounts of anaerobic mineral medium, and again diluted in shake series. The resulting colonies were checked for purity by microscopic control and by inoculation into AC-medium. Finally, 5 strains were chosen for further characterization.

Enumeration of gallate-degrading bacteria was carried out in two mud samples by the three-tube most probable number technique (American Public Health Association, 1969). In fresh water creek mud from Hannover, the MPN index of gallate degraders was 23 cells per $\mathrm{ml}$; in mud of Rio Marin, Venice, 240 cells per $\mathrm{ml}$ were found.

\section{Morphology}

Strains isolated from freshwater or marine mud did not differ markedly in morphology. Cells of marine isolated (Ma Gal 1, $\mathrm{Ma} \mathrm{Gal} 2$, Ma Phl 1) were short rods, $0.5-0.7 \times 1.0-2.5 \mu \mathrm{m}$, with rounded ends (Fig. 1 a). Cells of freshwater isolates (Ott Gal 1, Ott Gal 2) were often longer, $0.7 \times 1.5-4.0 \mu \mathrm{m}$ in size, and tended to form chains (Fig. 1b). Cell length varied; often cells of different length occurred in one single chain, and also coccoid minicells were observed (arrow). Dark granular inclusions appeared in the polar regions. Motility was occasionally observed in young cultures growing on gallic acid. Cells moved in a tumbling manner indicating subpolar or peritrichous flagellation. Motility, however, was lost early and could not be reproduced reliably. 


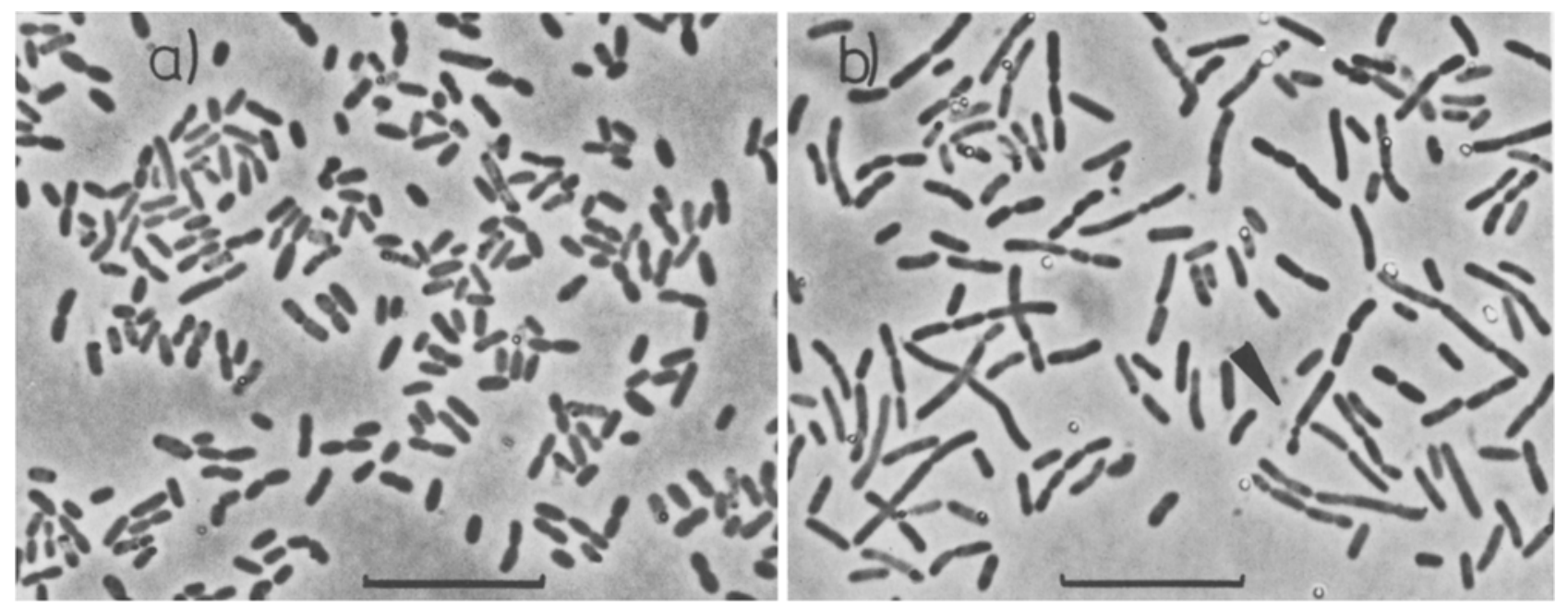

Fig. 1a, b. Phase contrast photomicrographs of isolates on gallic acid. a Marine isolate Ma Gal 2. b Freshwater isolate Ott Gal 1. Arrow points at a celi chain with cells of different lengths. Bar equals $10 \mu \mathrm{m}$ for both prints. Refractile particles are sulfur droplets in the medium

Cells of strain $\mathrm{Ma}$ Gal 1 tended to form clumps in all growth phases whereas the other strains clumped only in old cultures. All strains stained Gram-negative, and a typical Gram-negative cell wall structure was also proven by electron microscopic examination of ultrathin sections.

Spore formation could never be detected, neither in mineral medium nor in the sporulation media of Duncan and Strong (1968) or Hollaus and Sleytr (1972) nor in combinations of either two or all three. Enrichments from pasteurized mud samples $\left(15 \mathrm{~min}\right.$ at $80^{\circ} \mathrm{C}$ ) failed to degrade gallic acid.

\section{Physiological and Nutritional Properties}

All five isolated strains grew well in their respective isolation media, however, the two freshwater isolates often exhibited lag phases of several days after transfer. Although marine and fresh water isolates were similar with respect to all morphological and physiological properties they differed by their salinity requirements: Whereas the freshwater isolates Ott Gal 1 and Ott Gal 2 did not grow in marine medium or brackish water medium (containing half of the salt concentration of marine medium), the marine isolates did not grow in freshwater medium and only slowly with diminished yield in brackish water medium. No growth was found under aerobic or microaerobic conditions. Phosphate concentrations higher than $5 \mathrm{mM}$ retarded growth for several days; no growth was found at phosphate concentrations higher than $20 \mathrm{mM}$.

Vitamins as well as the trace elements selenium, molybdenum and tungsten were present in the isolation medium but were not required by pure cultures for at least five subsequent transfers. Yeast extract or other undefined additions were never needed by any isolate and did not enhance growth yields at all. Phloroglucinol, pyrogallol, gallic acid, and 2,4,6trihydroxybenzoic acid were the only substrates utilized. No mono- or dihydroxybenzenes were degraded, neither in the presence nor absence of Desulfovibrio vulgaris added as a hydrogen sink. No degradation of these phenols was either observed in the presence of other reducing agents like ascorbate, cysteine, or dithionite; neither growth nor changes of absorption spectra of these substrates could be detected.
Table 1. Substrates tested for degradation by strains $\mathrm{Ma}$ Gal 1, Ma Ga12, $\mathrm{Ma} \mathrm{Phl} 1$, and Ott Gal2

Substrates degraded:

Gallic acid, $10 \mathrm{mM}$; Phloroglucinol, $10 \mathrm{mM}$; Pyrogallol, $5 \mathrm{mM} ; 2,4,6-$ trihydroxybenzoic acid, $5 \mathrm{mM}$.

Substrates not degraded:

$2 \mathrm{mM}$ : Phenol, o-Cresol, Fructose, Glucose.

$5 \mathrm{mM}$ : Catechol, Resorcinol, p-Hydroquinone, Hydroxyhydroquinone, Salicylic acid, Protocatechuic acid, Cyclohexane carboxylic acid, Benzoic acid, Trihydroxycinnamic acid, Chinaic acid, meso-Inositol, Syringic acid, 3,4,5-Trimethoxybenzoic acid.

$10 \mathrm{mM}$ : Methanol, Ethanol, Glycerol, Formate, Glyoxylate, Glycolate, Pyruvate, Lactate, $\beta$-Hydroxybutyrate, Malonate, Succinate, Malate, L-Tartrate, Citrate, Fumarate, Nicotinate, Urate.

Mannitol, Lactose, Saccharose, Maltose, Salicin, Xylose, Arabinose, Cellobiose, Mannose, Melezitose, Raffinose, Sorbit, Rhamnose, Trehalose not fermented.

No formation of indole from tryptophan, no hydrolysis of urea, gelatine, or esculin. No catalase activity

The same was true for the third trihydroxybenzene isomer, hydroxyhydroquinone, for 3,4,5-trihydroxycynnamic acid or for methoxylated gallic acid derivatives like syringic acid or 3,4,5-trimethoxybenzoic acid. None out a of great variety of further substrates including sugars, organic mono- and dicarboxylic acids and alcohols was utilized. Neither nitrate or sulfate nor sulfur was reduced during degradation of gallic acid, pyrogallol, or phloroglucinol. The results of all substrate tests are summarized in Table 1. The only product formed was acetic acid. No other fatty acids nor lactate or alcohols could be detected. No gas other than carbon dioxide was produced.

The correlation between growth, substrate decomposition, and acetic acid formation is shown in Fig. 2 a for strain Ma Gal 2 grown on gallic acid. No qualitative change was found in absorption spectra of the culture supernatant as shown in Fig. 2 b indicating that no unsaturated intermediates were excreted. The maximum growth rate was $0.347 \mathrm{~h}^{-1}$, (minimum doubling time $2.0 \mathrm{~h}$ ) at $35^{\circ} \mathrm{C}$. No growth occurred at $9^{\circ} \mathrm{C}$ and at $40^{\circ} \mathrm{C}$. The $\mathrm{pH}$ limits were $\mathrm{pH} 5.3$ and 8.2 , the 
Table 2. Growth yields and stoichiometry of fermentation by strain Ma Gal2

\begin{tabular}{|c|c|c|c|c|c|c|}
\hline Substrate & $\begin{array}{l}\text { Amount of } \\
\text { substrate } \\
\text { degraded } \\
\text { (mmol) }\end{array}$ & $\begin{array}{l}\text { Cell dry } \\
\text { weight } \\
\text { formed } \\
(\mathrm{mg})\end{array}$ & $\begin{array}{l}\text { Acetate } \\
\text { assimi- } \text { lated }^{\mathrm{a}} \\
\text { (mmol) }\end{array}$ & $\begin{array}{l}\text { Acetate } \\
\text { produced } \\
(\mathrm{mmol})\end{array}$ & $\begin{array}{l}\text { Growth } \\
\text { yield: } \\
\text { mg per mol } \\
\text { substrate } \\
\text { utilized }\end{array}$ & $\begin{array}{l}\text { Carbon } \\
\text { recovery } \\
\%\end{array}$ \\
\hline Gallic acid & 2.5 & 25.38 & 0.522 & 7.0 & 10.1 & 101.0 \\
\hline Gallic acid & 5.0 & 51.18 & 1.05 & 13.9 & 10.2 & 99.7 \\
\hline Phloroglucinol & 2.5 & 24.72 & 0.509 & 6.9 & 9.9 & 98.8 \\
\hline Pyrogallol & 2.5 & 24.85 & 0.512 & 7.1 & 9.9 & 102.1 \\
\hline $\begin{array}{l}2,4,6 \text {-Trihydrobenzoic } \\
\text { acid }\end{array}$ & 2.5 & 24.07 & 0.496 & 6.9 & 9.6 & 98.6 \\
\hline
\end{tabular}

a Assimilated cell material was calculated from acetate as substrate by the equation: $17 \mathrm{CH}_{3} \mathrm{COOH} \rightarrow 8\left(\mathrm{C}_{4} \mathrm{H}_{7} \mathrm{O}_{3}\right)+2 \mathrm{CO}_{2}+6 \mathrm{H}_{2} \mathrm{O}$; thus, $0.0206 \mathrm{mmol}$ acetate are required for $1.0 \mathrm{mg}$ of cell dry weight. All figures are means of at least two independent assays. Cell dry weights were determined in $500 \mathrm{ml}$ cultures

optimum being at $6.5-7.0$. The maximum substrate concentrations tolerated were $20 \mathrm{mM}$ gallic acid and phloroglucinol, and $5 \mathrm{mM}$ pyrogallol.

\section{Growth Yield, Stoichiometry of Fermentation, and Coculture Experiments.}

The yields of acetate and cell dry matter obtained with strain $\mathrm{Ma} \mathrm{Gal} 2$ in marine medium are summarized in Table 2 . With all substrates, about $10 \mathrm{~g}$ cell dry weight per mol of substrate was formed. The yield was the same with strains Ma Gal 1 and $\mathrm{MaPhl} 1$, but was about $20 \%$ less with the freshwater isolates Ott Gal 1 and Ott Gal 2 although the same amounts of acetate were formed.

The total fermentation equation for gallic acid and 2,4,6trihydroxybenzoic acid reads as follows:

$\mathrm{C}_{7} \mathrm{H}_{5} \mathrm{O}_{5}^{-}+4 \mathrm{H}_{2} \mathrm{O} \rightarrow 3 \mathrm{CH}_{3} \mathrm{COO}^{-}+\mathrm{HCO}_{3}^{-}+3 \mathrm{H}^{+}$

for phloroglucinol and pyrogallol,

$$
\mathrm{C}_{6} \mathrm{H}_{6} \mathrm{O}_{3}+3 \mathrm{H}_{2} \mathrm{O} \rightarrow 3 \mathrm{CH}_{3} \mathrm{COO}-+3 \mathrm{H}^{+} \text {. }
$$

Cocultures of Methanosarcina barkeri and strain Ott Gal 1 degraded gallic acid stoichiometrically to methane and $\mathrm{CO}_{2}$. Acetate was an intermediary product. The overall equation of methane formation from gallic acid can be written as follows:

$$
\mathrm{C}_{7} \mathrm{H}_{5} \mathrm{O}_{5}+7 \mathrm{H}_{2} \mathrm{O} \rightarrow 3 \mathrm{CH}_{4}+4 \mathrm{HCO}_{3}^{-}+3 \mathrm{H}^{+} \text {. }
$$

In our experiment, $250 \mu \mathrm{mol}$ gallic acid was transformed to $743 \mu \mathrm{mol}$ methane; the remaining acetate in the medium was $<7 \mu \mathrm{mol}$ after 22 days of incubation.

In cocultures of Acetobacterium woodii and strain $\mathrm{Ma}$ Gal2, syringic acid was completely degraded to acetate; $250 \mu \mathrm{mol}$ syringic acid was converted to $1013 \mu \mathrm{mol}$ acetate; the theoretical value would be $1095 \mu \mathrm{mol}$ after subtraction of substrate assimilated into cell material.

\section{Pigments and DNA Base Composition}

Crude cell extracts of strain Ma Gal 2 with a protein content of about $10 \mathrm{mg} / \mathrm{ml}$ were subjected to spectrophotometric analysis. No pigments absorbing in the range of 400 to $650 \mathrm{~nm}$ could be detected, neither in air-oxidized nor dithionitereduced extracts. Redox difference spectra of dithionitereduced minus air-oxidized or minus ferricyanide-oxidized extracts did not give any indications for the presence of cytochromes either.
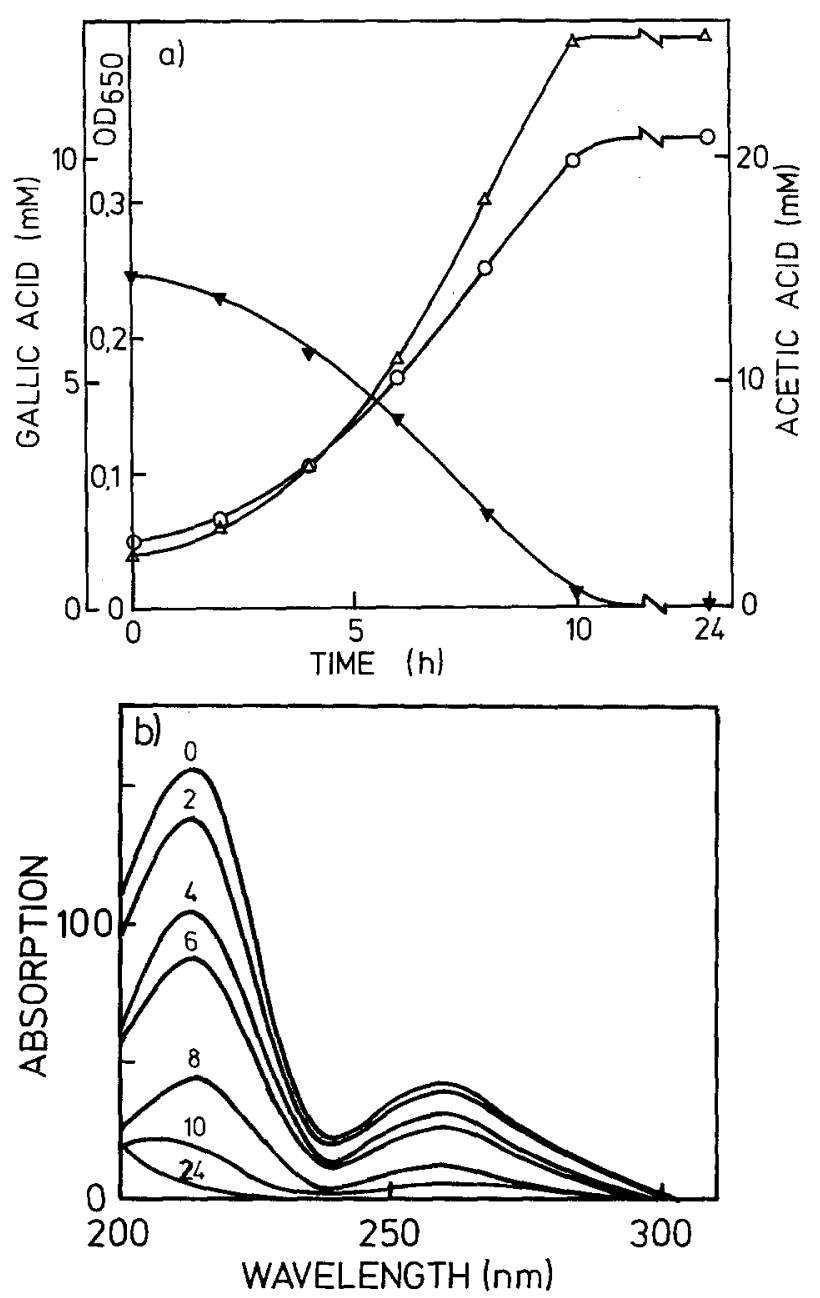

Fig. 2a. Fermentation time course of strain Ma Gal 2 on gallic acid. Experiments were performed at $30^{\circ} \mathrm{C}$ in $20 \mathrm{ml}$ tubes sealed with a Bellco rubber septum. Samples were removed by a syringe at times indicated and the headspace was flushed with $\mathrm{N}_{2} / \mathrm{CO}_{2}$ gas mixture. (O) Cell density, $(\triangle)$ acetic acid, ( $\mathbf{\nabla})$ gallic acid. $\mathbf{b}$ Absorption spectra of the growth medium in the same experiment. Numbers indicate the sampling times (in h). Samples were diluted $1: 2000$ for measurement

The guanine + cytosine content of the DNA of strain Ma $\mathrm{Gal} 2$ as determined by thermal denaturation was 51.8 $\pm 0.4 \mathrm{~mol} \%$ guanine + cytosine. 


\section{Discussion}

\section{Physiology of Substrate Degradation}

Aerobic degradation of aromatic compounds is well understood and involves a dioxygenase reaction as common step of ring cleavage (Ornston and Stanier 1966; Dagley 1975). In contrast, only few information exists on anaerobic degradation. Anaerobic photometabolism of benzoate was observed with Rhodopseudomonas palustris (Dutton and Evans 1969), Rhodospirillum fulvum (Pfennig et al. 1965) and Rhodocyclus purpureus (Pfennig 1978) and occurs via saturation of the benzene nucleus and subsequent hydrolytic cleavage (Dutton and Evans 1969; Guyer and Hegeman 1969; Whittle et al. 1976). A similar pathway is used by Pseudomonas sp. and Moraxella sp. in anaerobic, nitratedependent benzoate degradation (Taylor and Heeb 1972; Williams and Evans 1975) and is probably also active in benzoate degradation by sulfate-reducing bacteria (Widdel 1980). In the absence of external electron acceptors or light, methanogenic degradation of benzoate is possible and proceeds again via ring saturation (Fina et al. 1978; Keith et al. 1978); however, degradation was so far only observed in obligately syntrophic microbiologically undefined mixed cultures (Ferry and Wolfe 1976). The latter is also true for the anaerobic degradation of hydroxylated and methoxylated benzoic acid compounds derived from lignin (Healy and Young 1978, 1979); degradation via saturation of the aromatic ring is again assumed (Healy et al. 1980).

Anaerobic photoassimilation of phloroglucinol by pure cultures of Rhodopseudomonas gelatinosa was studied in detail (Whittle et al. 1976; Evans 1977). The degradation mechanism includes an initial NADPH-dependent reduction to dihydrophloroglucinol followed by enol-ketone-tautomerization, saturative hydratization and subsequent hydrolytic cleavage into pyruvate and a malonyl residue which both are assimilated into the intermediary metabolism.

Fermentative degradation of phloroglucinol was reported for pure cultures of Streptococcus bovis and Coprococcus sp. (Tsai and Jones 1975; Tsai et al. 1976). Ring cleavage started again with a NADPH-dependent reduction to dihydrophloroglucinol and followed probably the mechanism observed with $R$. gelatinosa (Patel et al. 1981). However, the fermentation balance given ( $2 \mathrm{~mol}$ acetate and $2 \mathrm{~mol} \mathrm{CO}_{2}$ per mol of phloroglucinol; Tsai et al. 1976) is not equilibrated since 8 electrons are not accounted for.

In the present paper we report on a new bacterium which was able to degrade four trihydroxybenzene isomers in defined mineral medium by fermentation to acetate ( $3 \mathrm{~mol} / \mathrm{mol}$ of substrate). To our knowledge, this is the first report on a completely fermentative degradation of phenolic compounds in pure cultures of bacteria. No substrates other than gallic acid, pyrogallol, phloroglucinol, and 2,4,6-trihydroxybenzoic acid were degraded, neither in pure culture nor in mixed culture with a sulfate-reducing bacterium. Pyrogallol and phloroglucinol are on the same redox level as sugars or acetic acid, and gallic acid and 2,4,6-trihydroxybenzoic acid should be easily convertible to pyrogallol and phloroglucinol by decarboxylation.

Only speculations are so far possible on the mechanism of degradation of the substrates utilized. Using the methods of Patel et al. (1981) we were able to measure with strain Ma Gal 2 a NADPH-dependent reduction of phloroglucinol with simultaneous increase of absorption at $278 \mathrm{~nm}$. This indicated the formation of dihydrophloroglucinol and suggests the same initial step in phloroglucinol degradation to occur in our organism as observed in $R$. gelatinosa and Coprococcus $s p$. However, this reaction was not observed with pyrogallol, gallic acid, or 2,4,6-trihydroxybenzoic acid as electron acceptors. Either these substrates are degraded by a different pathway or they have first to be transformed to phloroglucinol in a reaction not detectable under our assay conditions. In the case of pyrogallol, this transformation would need a para-transhydroxylation, either intra- or intermolecularly, a reaction not yet observed to occur in nature. It is of interest in this context that the third trihydroxybenzene isomer, hydroxyhydroquinone, which is not degraded by our isolates, cannot be altered by a para-transhydroxylation. On the other hand, this is the only trihydroxybenzene isomer not occuring in nature and thus no evolutionary pressure existed to develop a degradative system for it.

The high yield of cell dry matter $(10 \mathrm{~g} / \mathrm{mol})$ obtained with our isolates on all substrates utilized suggests basically similar degradation pathways for all of them. Since yields on mineral media with acetate as carbon source are usually around $10 \mathrm{~g} / \mathrm{Mol}$ ATP (Stouthamer 1979) the net yield of ATP in our case is probably in the range of $1-2 \mathrm{~mol} \mathrm{ATP} / \mathrm{mol}$ substrate.

\section{Ecological Considerations}

The question arises how an organism so specialized on a few "unusual" substrates can survive in nature and is present in the mud in modest numbers. Lignin as the main source of aromatic derivatives in nature is not degraded in its native state under anaerobic conditions (Zeikus 1980). Thus, only a small amount of monomers released during aerobic lignin depolymerization may reach anaerobic muds. It is of importance that during aerobic degradation the methoxyl groups are released only late after depolymerization (Donnelly et al. 1981). So the hydroxyl groups are protected from oxidation and phenol radical-catalyzed polymerization in aerobic environments. Oxidation products of e.g. pyrogallol or gallic acid were not metabolized by our organisms; if oxidized brownish substrate stock solutions were used for growth experiments only the "colourless" substrate monomers were fermented and the yellowish color remained unchanged. In the anoxic mud a metabiotic association of Acetobacterium woodii and our isolates may be able to demethoxylate and completely ferment the monomeric compounds. Acetate as the only fermentation product can then be easily converted to methane as shown in our experiments. A mixed culture system of $A$. woodii, our isolates, and $M$. barkeri or $M$. soehngenii would transform methoxylated gallic acid derivatives completely to methane and $\mathrm{CO}_{2}$ and thus could be the constituents of the undefined culture systems studied by Healy and Young 1978, 1979; Healy et al. 1980.

Low molecular weight phenols are important constituents of plant tissue, either as precursors of more complex phenolic compounds (lignins, phytoalexins) or in glycosylated or methoxylated form as easy-to-release antibacterial protectants (Pridham 1965). Dead plant material contains considerable amounts of these substances. Moreover, at least phloroglucinol is an important intermediary product of anaerobic degradation of bioflavonoids (Simpson et al. 1969), and pyrogallol is formed during aerobic resorcinol degradation (Groseclose and Ribbons 1981); however, the ecological importance of the latter process for anoxic environments has still to be examined. 


\section{Taxonomy}

The new isolates irrespective of their origin and salt requirements are similar with respect to substrate utilization, physiology, and cytological characteristics. As obligately anaerobic, Gram-negative, non-spoteforming rods they should be assigned to the Family Bacteroidaceae (Buchanan and Gibbons 1974). Due to their unique metabolism, our isolates cannot be assigned to any of the existing genera of the Bacteriodaceae (Bacteroides, Fusobacterium of Leptotrichia) which all ferment carbohydrates and produce a complex mixture of butyrate, lactate and other organic acids. For the same reason, assignment to the affiliated genera Butyrivibrio, Succinivibrio, Succinomonas, Lachnospira, and Selenomonas is not possible either. It appears necessary, therefore, to establish a new genus in the family Bacteroidaceae for our metabolically unusual, Gram-negative rods. We propose the name Pelobacter acidigallici for the new trihydroxybenzene derivatives-fermenting bacteria.

Genus Pelobacter gen. nov. Pe. lo. bac'ter. Gr. masc. n. pelos mud; bacter masc. equivalent of Gr. fem. n. bacteria rod or staff; M. L. masc. n. Pelobacter a mud-inhabiting rod.

Rod-shaped cells with rounded ends, single, in pairs or in chains. Motile forms occur. Gram-negative. Endospores not formed.

Chemoorganotrophic, metabolism fermentative. Strict anaerobes. Carbohydrates are not utilized. Media containing a reductant are necessary for growth; marine forms require $\mathrm{NaCl}$ concentrations higher than $1 \%$.

Habitats: anaerobic muds of limnic or marine origin.

Pelobacter acidigallici sp. nov. a.ci.di.gal' li.ci. M. L. neutr. n. acidum gallicum gallic acid, gen. acidigallici of gallic acid.

Rod-shaped cells, $0.5-0.8$ by $1.5-3.5 \mu \mathrm{m}$ in size, with rounded ends, single, in pairs or in chains. Motile in young cultures, however, motility may be lost early. No spore formation. Gram-negative.

Strictly anaerobic chemoorganotroph. Gallic acid, pyrogallol, 2,4,6-trihydroxybenzoic acid, and phloroglucinol are the only fermentable substrates, and acetate and $\mathrm{CO}_{2}$ are the only fermentation products. No other phenolic compounds, fatty acids, dicarbocylic acids, or alcohols metabolized. Sulfate, sulfur, or nitrate not reduced. Growth requires mineral media with a reductant. The marine type strain requires at least $10 \mathrm{~g} \mathrm{NaCl}$ and $1.5 \mathrm{~g} \mathrm{Mg} \mathrm{Cl}_{2}$ per 1 , whereas freshwater isolates do not need enhanced salt concentrations. No growth factors or vitamins are needed. Indole not formed, gelatine or urea not hydrolyzed. Selective enrichment with gallic acid or phloroglucinol as substrates.

$\mathrm{pH}$ range: $5.3-8.2$, optimum at $6.5-7.0$,

Temperatur range: $10^{\circ} \mathrm{C}-37^{\circ} \mathrm{C}$, optimum at $35^{\circ} \mathrm{C}$.

No cytochrome detectable.

DNA base ratio: $51.8 \% \mathrm{G}+\mathrm{C}$ (thermal denaturation)

Habitats: anaerobic muds of freshwater or marine origin.

Type strain: Ma Gal 2, DSM 2377, deposited in: Deutsche Sammlung von Mikroorganismen, Göttingen.

Acknowledgements. The authors want to thank Prof. Dr. Frank Mayer and his coworkers for electron microscopic characterization of the new isolates. Technical help by Andreas Tschech and helpful discussions with Regina Bache and Dr. Fritz Widdel are highly appreciated. This work was supported by a grant of the Deutsche Forschungsgemeinschaft.

\section{References}

American Public Health Association Inc. (Ed) (1969) In: Standard methods for the examination of water and waste-water including bottom sediments and sludge. New York pp 604-609

Bache R, Pfennig N (1981) Selective isolation of Acetobacterium woodii on methoxylated aromatic acids and determination of growth yields. Arch Microbiol 130:255-261

Bergmeyer HU (1965) Methods of enzymatic analysis. Verlag Chemie Weinheim, Germany

Buchanan RE, Gibbons NE (1974) Bergey's manual of determinative bacteriology, 8th ed Williams and Wilkins Co, Baltimore

Dagley S (1975) A biochemical approach to some problems of environmental pollution. Essays in Biochemistry 11:81-138

De Ley J (1970) Reexamination of the association between melting point, buoyant density and the chemical base composition of deoxyribonucleic acid. J Bacteriol 101:738-754

Donnelly MJ, Chapman PJ, Dagley S (1981) Bacterial degradation of 3,4,5-trimethoxyphenylacetic and 3-ketoglutaric acids. J Bacteriol $147: 477-481$

Duncan CL, Strong DH (1968) Improved medium for sporulation of Clostridium perfringens. Appl Microbiol 16:82-89

Dutton PL, Evans WC (1969) The metabolism of aromatic compounds by Rhodopseudomonas palustris. Biochem J 113:525-536

Evans WC (1977) Biochemistry of the bacterial catabolism of aromatic compounds in anaerobic environments. Nature (London) 270:1722

Ferry JG, Wolfe RS (1976) Anaerobic degradation of benzoate to methane by a microbial consortium. Arch Microbiol 107:3340

Fina LR, Bridges RL, Coblentz TH, Roberts FF (1978) The anaerobic decomposition of benzoic acid during methane formation. III. The fate of carbon four and the identification of propanoic acid. Arch Microbiol 118:169-172

Groseclose EE, Ribbons DW (1981) Metabolism of resorcinylic compounds by bacteria: new pathway for resorcinol catabolism in Azotobacter vinelandii. J Bacteriol 146:460-466

Guyer M, Hegeman G (1969) Evidence for a reductive pathway for the anaerobic metabolism of benzoate. J Bacteriol 99:906-907

Healy JB Jr, Young LY (1978) Catechol and phenol degradation by a methanogenic population of bacteria. Appl Environ Microbiol $35: 216-218$

Healy JB, Young LY (1979) Anaerobic biodegradation of eleven aromatic compounds to methane. Appl Environ Microbiol 38:8489

Healy JB, Young LY, Reinhard M (1980) Methanogenic decomposition of ferulic acid, a model lignin derivative. Appl Environ Microbiol $39: 436-444$

Hollaus F, Sleytr U (1972) On the taxonomy and fine structure of some hyperthermophilic saccharolytic clostridia Arch Mikrobiol $86: 129-146$

Keith CL, Bridges RL, Fina LR, Iverson KL, Cloran JA (1978) The anaerobic decomposition of benzoic acid during methane formation. IV. Dearomatization of the ring and volatile fatty acids formed on ring rupture. Arch Microbiol 118:173-176

Magee CM, Rodeheaver G, Edgerton MT, Edlich RF (1975) A more reliable gram staining technic for diagnosis of surgical infections. Am J Surg 130:341-346

Marmur J (1961) A procedure for the isolation of deoxyribonucleic acid from microorganisms. J Mol Biol 3:208-218

Ornston LN, Stanier RY (1966) The conversion of catechol and protocatechuate to $\beta$-ketoadipate by Pseudomonas putida. J Biol Chem 241:3776-3786

Pachmayr F (1960) Vorkommen und Bestimmung von Schwefelverbindungen in Mineralwasser. Thesis, Univ München

Patel TR, Jure KG, Jones GA (1981) Catabolism of phloroglucinol by the rumen anaerobe Coprococcus. Appi Environ Microbiol 42:10101017

Pfennig N (1978) Rhodocyclus purpureus gen. nov. and sp. nov., a ringshaped, vitamin $B_{12}$-requiring member of the family Rhodospirillaceae. Int $\mathbf{J}$ Syst Bacteriol 28:283-288 
Pfennig N, Eimhjellen KE, Liaaen-Jensen S (1965) A new isolate of the Rhodospirillum fulvum group and its photosynthetic pigments. Arch Mikrobiol 51:258-266

Pridham JB (1965) Low molecular weigh phenols in higher plants. Ann Rev Plant Physiol 16:13-36

Simpson FY, Jones GA, Wolin EA (1969) Anaerobic degradation of some bioflavonoids by microflora of the rumen. Can $\mathbf{J}$ Microbiol 15:972-974

Stouthamer AH (1979) The search for correlation between theoretical and experimental growth yields. In: International review of biochemistry, microbial biochemistry, Vol21, JR Quayle (ed) University Park Press, Baltimore, pp 1-47

Tarvin D, Buswell AM (1934) The methane formation of organic acids and carbohydrates. J Am Chem Soc 56:1751-1755

Taylor BF, Heeb MJ (1972) The anaerobic degradation of aromatic compounds by a denitrifying bacterium. Arch Mikrobiol 83:165171

Tsai CG, Gates DM, Ingledew WM, Jones GA (1976) Products of anaerobic phloroglucinol degradation by Coprococcus sp. $\mathrm{Pe}_{1} 5$. Can J Microbiol 22:159-164

Tsai CG, Jones GA (1975) Isolation and identification of rumen bacteria capable of anaerobic phloroglucinol degradation. Can J Microbiol $21: 794-801$
Whittle PJ, Lunt DO, Evans WC (1976) Anaerobic photometabolism of aromatic compounds by Rhodopseudomonas sp. Biochem Soc Trans $4: 490-491$

Widdel F (1980) Anaerober Abbau von Fettsäuren und Benzoesäure durch neu isolierte Arten Sulfat-reduzierender Bakterien. Thesis, Göttingen

Widdel F, Pfennig N (1981) Studies on dissimilatory sulfate-reducing bacteria that decompose fatty acids. I. Isolation of new sulfatereducing bacteria enriched with acetate from saline environments. Description of Desulfobacter postgatei gen. nov., sp. nov. Arch Microbiol 129:295-400

Williams RJ, Evans WC (1975) The metabolism of benzoate by Moraxella species through anaerobic nitrate respiration. Evidence for a reductive pathway. Biochem J 148:1-10

Zeikus JG (1980) Fate of lignin and related aromatics in anaerobic environments. In: Lignin biodegradation: Microbiology, chemistry and potential applications. Kirk T, Higushi $\mathrm{T}$, Chung HM (eds) CRC Press, Boca Raton, pp $101-110$

Received March 18, 1982/Accepted November 2, 1982 